\title{
The Molluscicidal Activity of the Latex of Euphorbia splendens var. hislopii on Melanoides tuberculata (Thiaridae), a Snail Associated with Habitats of Biomphalaria glabrata (Planorbidae)
}

\author{
Alexandre Giovanelli, Cesar Luiz Pinto Ayres Coelho da Silva ${ }^{+}$, \\ Luisa Medeiros*, Maurício Carvalho de Vasconcellos
}

\begin{abstract}
Departamento de Biologia, Instituto Oswaldo Cruz, Av. Brasil 4365, 21045-900 Rio de Janeiro, RJ, Brasil
*Escola Politécnica de Saúde Joaquim Venâncio-Fiocruz, Rio de Janeiro, RJ, Brasil
\end{abstract}

The use of the latex of Euphorbia splendens var. hislopii was considered as an effective control method for Biomphalaria glabrata in Sumidouro, Rio de Janeiro. However, the appearance and expansion of the snail Melanoides tuberculata since August 1997, with the concomitant reduction of the population of B. glabrata suggest that competitive exclusion might be taking place. Depending on the susceptibility of the thiarid to the E. splendens toxin, the natural control that is occurring could be interrupted by the employment of the latex if the planorbid were less susceptible to the toxin. The aim of this study is to investigate the molluscicidal activity of the latex on M. tuberculata. We used $420 \mathrm{M}$. tuberculata, from Sumidouro. Fourteen different latex concentrations were tested using World Health Organization general methodology. Probit analysis was used for $L D_{90}$ and $L D_{50}$ determination. The $L D_{50}$ was 3.57 $\mathrm{mg} / \mathrm{l}$ and $L D_{90}$ was $6.22 \mathrm{mg} / \mathrm{l}$. At the highest concentration $(10 \mathrm{mg} / \mathrm{l})$ there was no survival. No significant differences among replicas $\left(\chi^{2}=8.31 ; \mathrm{gl}=13 ; \mathrm{p}>0.05\right)$ were found. The $L D_{90}$ dose for $\mathrm{M}$. tuberculata was 13.8 times greater than that for $\mathrm{B}$. glabrata, so that the molluscicide in the presence of the thiarid may have a synergic effect on reduction of Biomphalaria populations.

Key words: molluscicide - Euphorbia splendens - Melanoides tuberculata - Biomphalaria glabrata schistosomiasis

Since 1991 our group has been making an ecoepidemiological study in Sumidouro, Rio de Janeiro, Brazil, to verify the abundance of Biomphalaria glabrata (Say, 1818) and its degree of infection with schistosomiasis. The use of latex from Euphorbia splendens, which has good molluscicidal action against Biomphalaria (Vasconcellos \& Schall 1986, Baptista et al. 1992, Mendes et al. 1992, 1997 Schall et al. 1998), was planned as a schistosomiasis control measure in this area. However, in August 1997 the presence of Melanoides tuberculata (Muller, 1774) was detected. This snail genus has medical and veteri-

\footnotetext{
The authors dedicate this paper in honour of the Oswaldo Cruz Institute, on the occasion of the centenary of its foundation, May 25th 1900.

${ }^{+}$Corresponding author. Fax:+55-21-560.6474. E-mail: cesarcs@gene.dbbm.fiocruz.br

Received 20 March 2000

Accepted 7 June 2000
}

nary interest because some species act as intermediate hosts of pathogenic helminths to man [Paragonimus sp., Clonorchis sp. (Pessoa \& Martins 1982, Kino et al. 1998) and Centrocestus formosanus (Pointier 1999)]. Nevertheless this species could be useful in the biological control of planorbids that are intermediate hosts of Schistosoma mansoni (Prentice 1983 Pointier \& Mccullough 1989, Pointier et al. 1989, Gomez et al. 1990, Gomez Perez et al. 1991, Pointier \& Guyard 1992, Schlegel et al. 1997), the helminth responsible for schistosomiasis in Brazil.

Since the detection of the M. tuberculata population in Sumidouro there has been a severe decline in the B. glabrata population concomitant with the Melanoides species population growth and expansion indicating a process of competitive exclusion. The use of the toxin from E. splendens could therefore have a negative effect on control if it were more toxic towards on $M$. tuberculata than to $B$. glabrata.

The aim of this study was to verify the effects of the latex of E. splendens on M. tuberculata collected in B. glabrata habitats at Porteira Verde valley in Sumidouro. 


\section{MATERIALS AND METHODS}

The latex from E. splendens var. hislopii NEB [Sin. Euphorbia milii Des Moul. Var. splendens (Hook.) Ursh \& Leandri (Carter 1994)] was extracted from cuts made on the trunk. The plants used were grown in experimental plots located in the Fiocruz campus. One $\mathrm{ml}$ of latex was diluted in $9 \mathrm{ml}$ of distilled water. Fourteen different concentrations were prepared following the World Health Organization standard method of 1983 (0; $0.2 ; 0.4 ; 0.6 ; 0.8 ; 1 ; 2 ; 2.5 ; 3 ; 3.5 ; 4 ; 4.5 ; 5 ; 10 \mathrm{mg} /$ 1).

Four hundred twenty $M$. tuberculata snails from Sumidouro were used. Shell sizes varied from 16 to $27 \mathrm{~mm}$ in length. For each concentration two beakers each with 15 snails (experiment and replicate) were used to complete 30 snails per concentration. Exposure was for $24 \mathrm{~h}$ after which the number of snails apparently dead was noted and the solution was replaced by distilled water. After further $24 \mathrm{~h}$, the number of the dead snails was again counted. No food was supplied during the experiment.

Lethal doses for $50 \%$ and $90 \%$ of the population $\left(\mathrm{LD}_{50}\right.$ and $\left.\mathrm{LD}_{90}\right)$ were obtained by Probit analysis, using the computer software of Finney (1971). Differences between replicas were verified using the chi-square test.

\section{RESULTS}

After exposure to the molluscicide, many snails had retracted into their shells, especially at the highest concentrations used, and their mobility was reduced. However, after the recovery period many snails returned to normal behaviour.

Concentrations of $2 \mathrm{mg} / \mathrm{l}$ or higher triggered intense mucus production but no escape behaviour was observed. Mortality started to occur at concentrations of $2.5 \mathrm{mg} / \mathrm{l}$. The $\mathrm{LD}_{50}$ was $3.6 \mathrm{mg} / \mathrm{l}$ and the $\mathrm{LD}_{90}$ was $6.2 \mathrm{mg} / \mathrm{l}$. At the highest concentration $(10 \mathrm{mg} / \mathrm{l})$ there were no survivors (Fig. 1).

No significant differences were observed between replicas $\left(\chi^{2}=8.31 ; \mathrm{gl}=13 ; \mathrm{p}>0.05\right)$.

\section{DISCUSSION}

Mkoji et al. (1992) speculated that the use of molluscicide in areas where both $B$. pfeifferi and $M$. tuberculata occur would have negative effects on the control of schistosomiasis. The molluscicide would potentially affect the $M$. tuberculata population causing a diminution of the competitive pressure on the Biomphalaria sp. population. As a consequence, an increase in the Biomphalaria sp. population would be noted soon after the initial impact of the molluscicide.

However, the results obtained in this study demonstrate that this effect is not to be expected with the use of the latex of E. splendens, at least with the studied populations. The $\mathrm{LD}_{90}$ of $0.45 \mathrm{mg} / \mathrm{l}$ for the B. glabrata control (Vasconcellos \& Schall 1986 ) is 13.8 times lower than $\mathrm{LD}_{90}$ for $M$. tuberculata. Even the dosages used for the control of $B$. glabrata in the field are under the $\mathrm{LD}_{50}$ encountered for M. tuberculata in the present study. So the utilization of the latex of E. splendens in areas where both $M$. tuberculata and B. glabrata are present, should not reduce the Melanoides population and might even have a synergetic effect in reducing the $B$. glabrata population.

The introduction of $M$. tuberculata as a control measure for Biomphalaria should be considered with caution (WHO 1984) since M. tuberculata is an intermediate host for other parasites especially Paragonimus spp. that can affect the human population (Pessoa \& Martins 1982). The transmission of paragonomiasis occurs through the ingestion of raw infected crustaceans (a second intermediate host), a habit that is spreading among fishermen and near-shore populations that inhabit the Paraná and Rio Grande rivers (State of São Paulo) in Brazil. The probability of autochthonous cases in these areas is high (Vaz et al. 1986). Besides, the effect of M. tuberculata populations on the bentonic macroinvertebrate fauna and on other organisms is very little known in the neotropics.

To complement the results obtained experiments in the field at different times of the year are necessary.

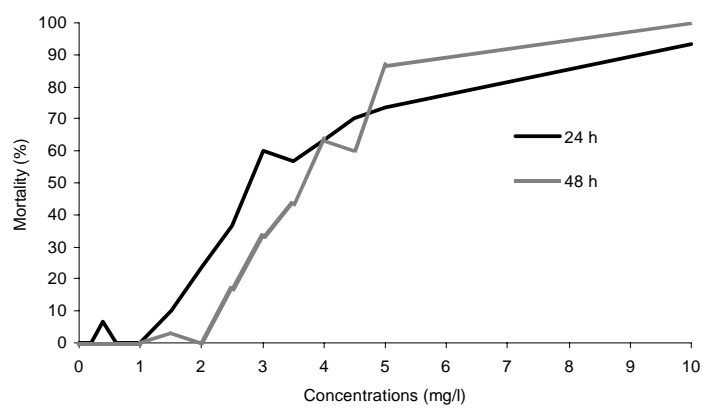

Mortality (\%) of Melanoides tuberculata after being exposed to the latex of Euphorbia splendens (var. hislopii) during 24 $\mathrm{h}$, followed by $48 \mathrm{~h}$ recovery period in distilled water.

\section{ACKNOWLEDGEMENTS}

To Valdinei Valim for the technical assistance and to Marisa S Soares, from the Biology Department, for the suggestions and criticism. To Dr Eric S Loker, from The University of New Mexico, for the relevant comments and for revision of the English version. 


\section{REFERENCES}

Baptista DF, Vasconcellos MC, Lopes FEF, Silva IP, Schall VT 1992. Evaluation of the molluscicidal properties of Euphorbia splendens var. hislopii (N.E.B.) (Euphorbiaceae) - 2. Investigation in lotic habitat. Mem Inst Oswaldo Cruz 87: 549-553.

Carter S 1994. A preliminary classification of Euphorbia subgenus Euphorbia. Ann Missouri Bot Gard 81: 368-379.

Finney DJ 1971. Probit Analisys, 3rd ed., Cambridge University Press, New Delhi, 333 pp.

Gomes JD, Vargas M, Malek EA, 1990. Biological control of Biomphalaria glabrata by Thiara granifera under laboratory conditions. Trop Med Parasit 41: 43-45.

Gomez Perez J, Vargas M, Malek EA 1991. Displacement of Biomphalaria glabrata by Thiara granifera under natural conditions in the Dominican Republic. Mem Inst Oswaldo Cruz 86: 341-347.

Kino H, Inaba H, De NV, Chau LV, Son DT, Hao HT, Toan ND,Cong LD, Sano M 1998. Epidemiology of Clonorchiasis in Ninh Binh Province, Virtnam. Southeast Asian J Med Public Health 29: 250-254.

Mendes NM, Baptista DF, Vasconcellos MC, Schall VT 1992. Evaluation of the molluscicidal properties of Euphorbia splendens var. hislopii (N.E.B.) (Euphorbiaceae) - 1. Experimental test in a lentic habitat. Mem Inst Oswaldo Cruz 87: 21-23.

Mendes NM, Vasconcellos MC, Baptista DF, Rocha RS, Schall VT 1997. Evaluation of the molluscicidal properties of Euphorbia splendens var. hislopii (N.E.B.) latex: experimental test in an endemic area in the state of Minas Gerais, Brazil. Mem Inst Oswaldo Cruz 92: 719-724.

Mkoji GM, Mungai BN, Koech DK, Hofkin BV, Loker ES, Kihara JH, Kageni FM 1992. Does the snail Melanoides tuberculata have a role in biological control of Biomphalaria pfeifferi and other medically important African pulmonates? Ann Trop Med Parasitol 86: 201-204.

Pessoa SB, Martins AV 1982. Parasitologia Médica, 11th ed., Guanabara, Rio de Janeiro 872 pp.

Pointier JP 1999. Invading freshwater gastropods: some conflicting aspects for public health. Malacologia
41: 403-411.

Pointier JP, Guyard A 1992. Biological control of snail intermediate hosts of Schistosoma mansoni in Martinique, French West Indies. Ann Trop Med Parasitol 43: 98-101.

Pointier JP, Mccullough F 1989. Biological control of the snail hosts of Schistosoma mansoni in the Caribbean area using Thiara spp. Acta Trop 46: 147-155.

Pointier JP, Guyard A, Mosser A 1989. Biological control of Biomphalaria glabrata and B. straminea by the competitor snail Thiara tuberculata in a transmission site of schistosomiasis in Martinique, French West Indies. Ann Trop Med Parasitol 83: 263-269.

Prentice MA 1983. Displacement of Biomphalaria glabrata by the snail Thiara granifera in field habitats in St. Lucia, West Indies. Ann Trop Med Parasitol 77: 51-59.

Schall VT, Vasconcellos MC, Souza CP, Baptista DF 1998. The molluscicidal activity of crown of Christ (Euphorbia splendens var. hislopii) latex on snails acting as intermediate hosts of Schistosoma mansoni and Schistosoma haematobium. Am J Trop Med Hyg 58: 7-10.

Schlegel L, Pointier JP, Petitjean-Roget V, Nadeau Y, Blateau A, Mansuy JM 1997. Le contrôle de la schistosomose intestinale de l'île de la Martinique. Parasite 4: 217-225.

Vasconcellos MC, Schall VT 1986. Latex of "Coroa de Cristo" (Euphorbia splendens): an effective molluscicide. Mem Inst Oswaldo Cruz, 81: 475-476.

Vaz JF, Teles HMS, Correa MA, Silva Leite SP 1986. Ocorrência no Brasil de Thiara (Melanoides) tuberculata (Muller,1774) (Gastropoda, Prosobranchia), primeiro hospedeiro intermediário de Clonorchis sinensis (Cobbold,1875) (Trematoda, Plathyhelmintes). Rev Saú Públ São Paulo 20: 318322.

WHO-World Heath Organization 1983. Report of scientific working group on plant molluscicide and guidelines for evaluation of plant molluscicide. Geneva TDR/SCH-SWE4/83:3.

WHO-World Heath Organization 1984. Report of an informal consultation on research on the biological control of snail intermediate hosts. $T D R / B C V-S C H /$ SIH/84: 1-39. 